\title{
Symptomatic vertebral haemangioma: endovascular treatment of 12 patients
}

\author{
PN Jayakumar, MK Vasudev and SG Srikanth \\ Department of Neuroradiology, National Institute of Mental Health and Neuro Sciences, Bangalore- 560029, India
}

\begin{abstract}
Vertebral haemangioma is a well known albeit infrequent cause for thoracic cord compression. While surgery is the treatment of choice in patients with neural compression syndromes, embolization of the feeding arterial pedicles is less frequently practiced. Twelve patients with vertebral haemangiomas and neural compression underwent particulate embolization of the feeder arteries. Eleven patients had a subsequent decompressive laminectomy. At 8 months of follow-up after radiotherapy, eleven patients had improved and in one patient, the clinical deficits were unchanged. Immediate pre-operative particulate embolization is to be considered in patients with a symptomatic spinal haemangioma.
\end{abstract}

Keywords: vertebral haemangioma; spinal cord compression; spinal angiography; embolization; decompressive laminectomy; neoplasm resection

\section{Introduction}

Vertebral haemangiomas rarely present with spinal cord or nerve root compression requiring intervention. ${ }^{1-5}$ They are more often discovered incidentally or are detected during the evaluation of back ache. ${ }^{6}$ Decompressive surgery with or without postoperative radiation has been the therapy recommended for lesions causing spinal cord compression. ${ }^{5-9}$ Embolization is currently being used either preoperatively or sometimes as the definitive mode of treatment. ${ }^{10-14}$ Our experience in the management of 12 patients with symptomatic vertebral haemangioma is discussed.

\section{Patients and methods}

The medical and radiological records of 12 patients who presented with spinal cord compression due to a vertebral haemangioma between 1987 and 1994 have been reviewed (Table 1). There were three males and nine females, the ages ranging from 12 to 50 years. All the patients presented with paraparesis and local spinal tenderness. Six had a moderate to severe degree of deficit with a score of less than 45 on the ASIA motor index score and Frankel's grade $\mathrm{A}-\mathrm{C} .{ }^{15}$

Neuroradiological evaluation consisted of plain films of the spine and Computed Tomography (CT). Pluridirectional tomography and myelography were performed in a few cases. MRI was not done as it is not available at our centre. All patients underwent selective spinal angiography irrespective of the findings of other examinations.

All the patients had particulate embolization of all the feeder arteries, without steroid cover. Lyophilised

Correspondence: PN Jayakumar dura was used in six patients, gelfoam in five and cyanoacrylate in one. Nonvisualization of the tumor blush and stasis of the contrast medium in the feeding arteries were considered as endpoints of embolization.

Decompressive laminectomy was done in 11 patients. A dorsal soft tissue epidural mass was seen at surgery in seven patients and was resected. Anterior decompression of the soft tissue haemangiomatous mass or corpectomy was not done as the tumor had been embolized and the patients were being referred for radiotherapy. One patient refused surgery after endovascular intervention was stopped after approximately $75 \%$ embolization as he refused to co-operate further. He did not develop any increase of the neurological deficit. All the patients underwent radiotherapy, following embolization. By 8 months after radiotherapy, 11 of the 12 patients had recovered well. The motor deficit has remained unchanged in one patient.

\section{Results}

Plain X-rays and CT scans (Figure 1) were diagnostic in all the patients and the haemangioma was seen at three contigeous levels in one patient. The vertebral bodies were involved in all the patients and the pedicle in 11. The posterior arches were also involved in six of the patients. Neural compression was due to a soft tissue mass in seven patients, and a combination of a soft tissue mass and bone in three others. A bilateral segmental arterial supply was the commonest feature. In three patients, the haemangiomatous mass derived an additional blood supply from adjacent radicular branches.

Complete angiographic avascularity of the tumor 
Table 1 Clinical radiological and pathological details in patients with spinal haemangioma

\begin{tabular}{|c|c|c|c|c|c|c|c|c|c|c|c|}
\hline $\begin{array}{l}\text { SI. } \\
\text { no. }\end{array}$ & $\begin{array}{l}\text { Age/ } \\
\text { sex }\end{array}$ & $\begin{array}{l}\text { Duration } \\
\text { of } \\
\text { illness }\end{array}$ & Level & $\begin{array}{l}\text { Radiol } \\
\text { Type } \\
\text { of } \\
\text { invol }\end{array}$ & $\begin{array}{l}\text { cal } \\
\text { Intra- } \\
\text { spinal } \\
\text { mass }\end{array}$ & $\begin{array}{l}\text { Features } \\
\text { para- } \\
\text { spinal } \\
\text { mass }\end{array}$ & $\begin{array}{l}\text { Intervention } \\
\text { particle } \\
\text { used }\end{array}$ & $\begin{array}{l}\text { Angiographic } \\
\text { obliteration }\end{array}$ & Surgery & $\begin{array}{l}\text { Clinical } \\
\text { outcome }\end{array}$ & $\begin{array}{l}\text { Histopath- } \\
\text { ology type }\end{array}$ \\
\hline 1 & $22 / \mathrm{M}$ & 3 Months & T5 & $\mathrm{B}, \mathrm{P}, \mathrm{L}$ & Soft tissue & + & Dura & Total & $\begin{array}{l}\text { Decomp. } \\
\text { lamin. }\end{array}$ & Improved & Cavernous \\
\hline 2 & $32 / \mathrm{F}^{*}$ & 1 Months & $\mathrm{T} 6$ & $\mathrm{~B}, \mathrm{P}$ & Soft tissue & + & Dura & Subtotal & No & Improved & N.A. \\
\hline 3 & $21 / \mathrm{F}$ & 7 Months & $\mathrm{T} 12$ & $\mathrm{~B}, \mathrm{P}, \mathrm{L}$ & - & & Dura & Total & $\begin{array}{l}\text { Decomp. } \\
\text { lamin. }\end{array}$ & Improved & $\begin{array}{l}\text { Cavernous } \\
\text { and capillary }\end{array}$ \\
\hline 4 & $40 / \mathrm{F}$ & 21 days & T6 & $\mathrm{B}, \mathrm{P}, \mathrm{L}$ & $\begin{array}{l}\text { Soft tissue } \\
\text { and bone }\end{array}$ & + & Gelfoam & Total & $\begin{array}{l}\text { Decomp. } \\
\text { lamin. }\end{array}$ & Improved & Capillary \\
\hline 5 & $50 / \mathrm{F}^{* *}$ & 1 Year & $\begin{array}{l}\text { T11, } \\
\text { L1-2 }\end{array}$ & $\mathrm{B}, \mathrm{P}, \mathrm{L}$ & Soft tissue & + & Dura & Total & $\begin{array}{l}\text { Decomp. } \\
\text { lamin. }\end{array}$ & Improved & Capillary \\
\hline 6 & $12 / \mathrm{F}$ & 1 Months & $\mathrm{T} 4$ & $\mathrm{~B}, \mathrm{P}, \mathrm{L}$ & $\begin{array}{l}\text { Soft tissue } \\
\text { and bone }\end{array}$ & - & Gelfoam & Total & $\begin{array}{l}\text { Decomp. } \\
\text { lamin. }\end{array}$ & Status quo & $\begin{array}{l}\text { Capillary and } \\
\text { cavernous }\end{array}$ \\
\hline 7 & $25 / \mathrm{F}$ & 2 Months & L1 & $\mathrm{B}, \mathrm{P}, \mathrm{L}$ & Soft tissue & + & Gelfoam & Total & $\begin{array}{l}\text { Decomp. } \\
\text { lamin. }\end{array}$ & Improved & Capillary \\
\hline 8 & $21 / \mathrm{M}$ & 4 Months & L1 & $\mathrm{B}, \mathrm{P}$ & - & & Dura & Total & $\begin{array}{l}\text { Decomp. } \\
\text { lamin. }\end{array}$ & Improved & Cavernous \\
\hline 9 & $12 / \mathrm{F}$ & 2 Months & T9 & $\mathrm{B}, \mathrm{P}$ & Soft tissue & + & Gelfoam & Total & $\begin{array}{l}\text { Decomp. } \\
\text { lamin. }\end{array}$ & Improved & $\begin{array}{l}\text { Capillary and } \\
\text { cavernous }\end{array}$ \\
\hline 10 & $20 / \mathrm{M}$ & 2 Months & T9 & $\mathrm{B}, \mathrm{P}, \mathrm{L}$ & Soft tissue & + & Dura & Total & $\begin{array}{l}\text { Decomp. } \\
\text { lamin. }\end{array}$ & Improved & Cavernous \\
\hline 11 & $14 / F$ & 14 days & $\mathrm{T} 7$ & $\mathrm{~B}, \mathrm{P}, \mathrm{L}$ & $\begin{array}{l}\text { Soft tissue } \\
\text { Soft tissue }\end{array}$ & $\begin{array}{l}+ \\
+\end{array}$ & Gelfoam & Total & $\begin{array}{l}\text { Decomp. } \\
\text { lamin. }\end{array}$ & Improved & Cavernous \\
\hline 12 & $21 / \mathrm{F}$ & 2 Months & $\mathrm{T} 4$ & B & and bone & - & Histocryl & Total & $\begin{array}{l}\text { Decomp. } \\
\text { lamin. }\end{array}$ & Improved & Capillary \\
\hline
\end{tabular}

*Patient had multiple soft tissue haemangioma; **Only $\mathrm{T}_{11}$ symptomatic. $\mathrm{B}$ - body; $\mathrm{P}-$ Pedicle; $\mathrm{L}-$ Lamina

mass was achieved in all of the patients except in one patient in whom intervention was stopped after nearly $75 \%$ occlusion on one side; due to events unrelated to the procedure. While none of the patients deteriorated after intervention, four showed mild improvement by the fourth day of intervention but were nevertheless operated.

The results of embolotherapy, the type of particulate matter used and the duration between intervention and surgery were compared. While there were no differences between the type of particles used, surgery beyond day 5 of intervention (two patients) was associated with brisk bleeding from the tumor and the tumor mass in those operated within 4 days of intervention (seven patients) was relatively avascular except in the solitary case of incomplete embolization. There was complete absence of blood loss in the solitary patient treated with transarterial N-butyl cynoacrylate embolization. On follow up, four patients were in Frankel's scale D (ASIA score 4549 ) and five were normal (score $=50)$. One patient in scale A (score 25) did not improve with treatment while another on scale B (score 38) improved by two grades (D, score 43).

\section{Discussion}

Vertebral haemangioma, a common and benign condition of the spinal column, may be either asymptomatic or may present with local pain and rarely a spinal cord compression syndrome., ${ }^{3,6,16}$ The pathogenetic mechanisms of cord compression in spinal haemangiomas include (1) Epidural soft tissue angiomatous mass, ${ }^{3,8}$ (2) Expansion of the bony elements, ${ }^{8}$ (3) Compression fracture of the vertebra ${ }^{11,12,17}$ and (4) Epidural haematoma. ${ }^{18}$

The preoperative diagnosis remains an essential prerequisite for precise management. While we agree with Healy et al, that the clinical presentation of spinal pain, radiculopathy and paraparesis is similar to other diseases such as primary lymphoma and metastatic tumor, ${ }^{8}$ one can make a diagnosis of a spinal osseous haemangioma with a reasonable degree of accuracy by appropriate investigations. ${ }^{19}$ Rarefaction and exaggerated vertical striations or a course honeycombed appearance are characteristic features in the plain radiographs, though they are seen in a minority $(41 \%)$ of patients. ${ }^{20}$ However, plain radiographs were diagnostic in all of the patients in our study, due to the fact that we were evaluating a symptomatic population with precise neurological deficits.

The contribution of myelography lies in the demonstration of different degrees and extent of compression. The CT features of haemangioma of the spine are varied. While Schnyder et al considered the polka-dot pattern of the vertebral body pathognomonic, it was not seen in all cases. ${ }^{21}$ There could be 
variable destruction of the vertebral body, pedicles and the laminae. Enhancing intraspinal and paraspinal
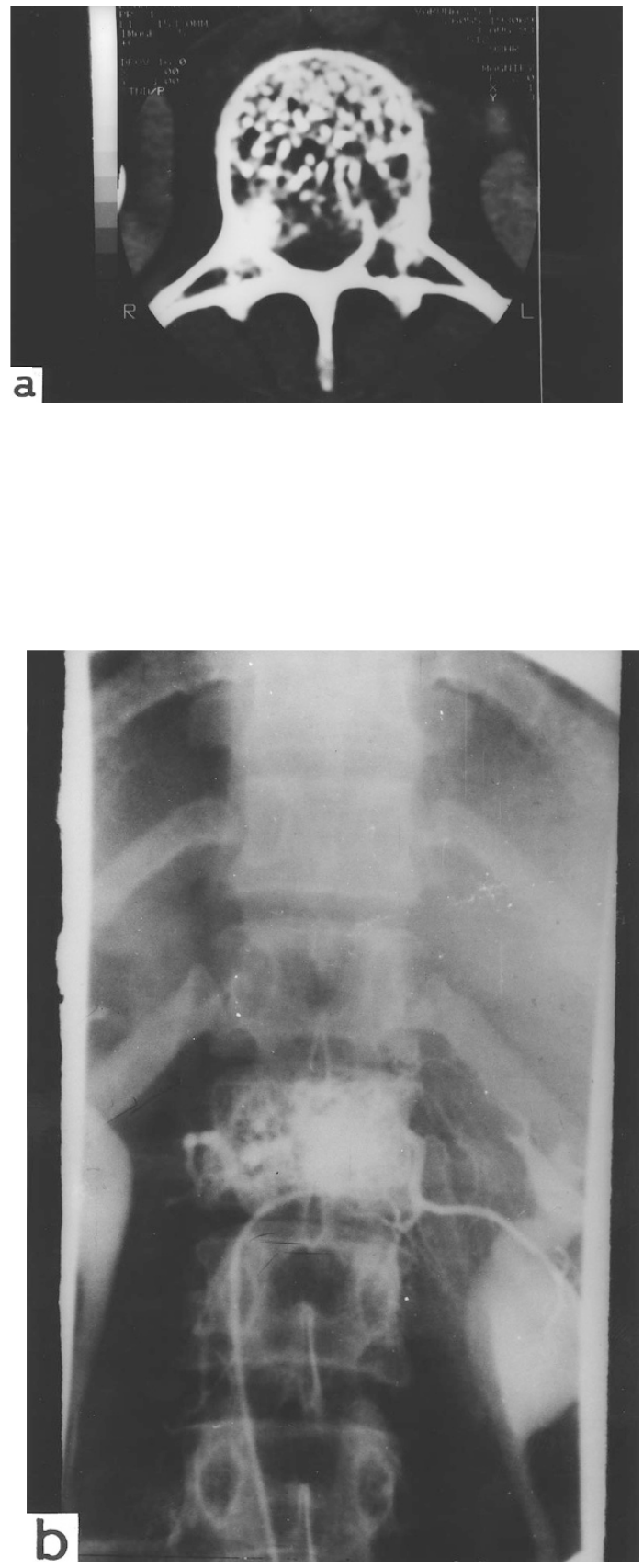

Figure 1 CT Scan (a) shows the coarse trabeculations characteristic of haemangioma with the mass encroaching the spinal canal. Selective left (b) and right (c) lumbar arteriography shows intense vascular blush in the haemangiomatous vertebra. Delayed phase of the post intervention angiogram (d) shows complete obliteration of the blush. Histopathological subtype: Cavernous haemangioma angiomatous masses are well demonstrated by the CT scan. MRI has recently added some additional features
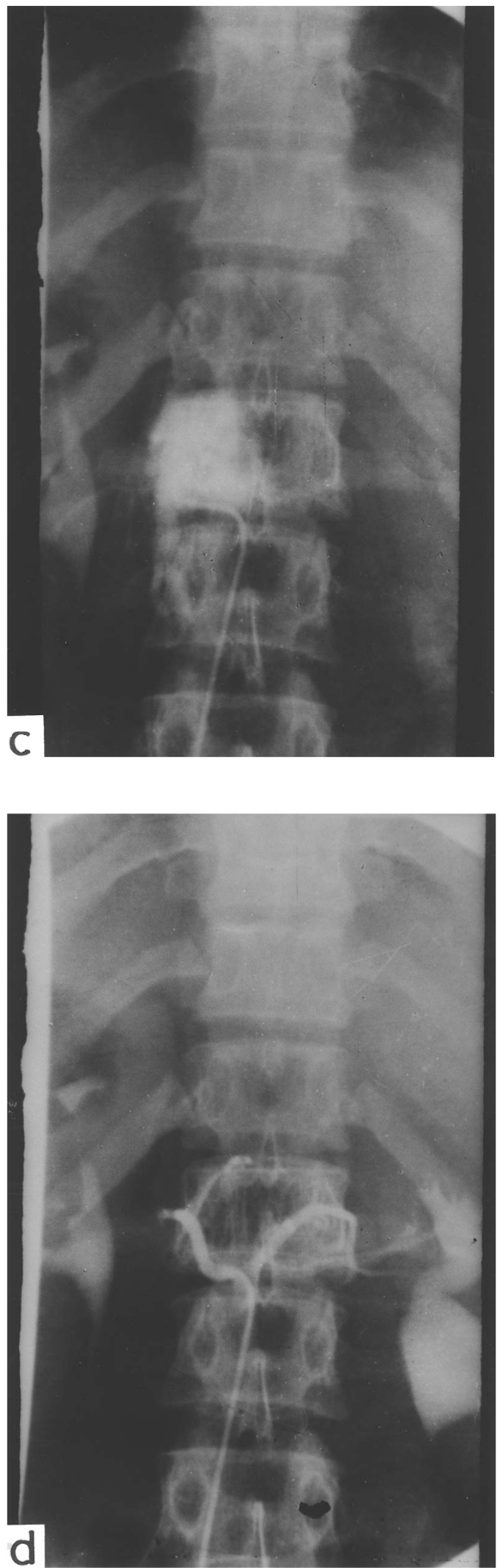
suggestive of haemangioma which include increased signal intensity on T1 weighted images, marked degree of increased signal on T2 weighted images with mottled appearance of the vertebral bodies. ${ }^{22}$

All of our patients underwent selective angiography and embolization of the arterial feeders. The results of embolization was excellent in our study as is reflected by the minimal or relatively absent blood loss in seven of the 11 patients who underwent surgery.

Brisk bleeding in two patients, we feel could have been due to the delay between embolization and surgery with consequent recanalization and collateral supply.

This is in spite of the fact that the tumor was highly vascular in all the cases with unisegmental or multisegmental blood supply. The choice of the embolization material used in the literature is varied. While some centres have used Isobutyl Cyanoacrylate $^{13}$ some do not mention the embolization materials used. ${ }^{5,14}$ Particulate matter in the form of gelfoam and duramater was used in eleven of our patients. While the type of particle used did not relate to the degree of blood loss at surgery, the interval between intervention and surgery did. Hence, if surgery is planned it may preferably be done within 2 to 4 days of particulate embolization. The relative merits of the liquid embolizing materials versus the particulate materials for spinal haemangiomas is not clear, considering the technical difficulties of using liquid glue. While Gaston reported the use of transarterial histoacryl embolization in three cases, ${ }^{23}$ Nicola and Lins described intra-operative retrograde embolization. ${ }^{13}$ In the solitary case in which it was used by us, surgery was totally free of blood loss, the haemangiomatous mass had completely shrunk and spinal cord pulsations were clearly discernable at laminectomy.

While the presence of soft tissue compression of the cord may suggest a risk from embolization due to a sudden increase in the size of the mass, we feel that this is more of a problem with solid tumors than from a soft compressible haemangioma composed of cavernous blood spaces. A more definitive risk of embolization would be spinal cord ischemia due to inadvertant embolization of the artery of Adamkiewicz (AA). None of our patients showed the AA arising from the tumor pedicles, albeit on non-digital angiography. However, large sized particles are safe as they are unlikely to enter the AA unlike liquid glue.

Some authors have suggested embolization as a definitive mode of therapy. ${ }^{1,24}$ It is our opinion and of a few others that particulate embolization alone may be inadequate and is to be considered as the procedure of choice to reduce intraoperative bleeding. $5,6,11,14,25$

The role of radiotherapy for haemangiomas of the spine is still unsettled. In patients with subtotal removal as is most often the case with extensive lesions of the spine and given that vertebral haemangiomas are radiosensitive lesions, routine post-operative radiotherapy has been recommended. ${ }^{26}$ Fractionated doses under $40 \mathrm{GY}$ are considered to carry minimal risks. ${ }^{26}$

It is our experience that embolization of the feeder arteries should be a routine pre-operative procedure. It is safe in skilled hands and is not associated with any morbidity: postinterventional surgery is bloodless, easier, and the outcome is good.

\section{References}

1 Krueger EG, Sobel GL, Weinstein C. Vertebral haemangioma with compression of spinal cord. J Neurosurg 1961; 18: 331 - 338 .

2 Bergstrand A, Hook O, Lidvall H. Vertebral haemangiomas compressing the spinal cord. Acta Neurol Scand 1963; 39: 59-66.

3 McAllister VL, Kendall BE, Bull JWD. Symptomatic vertebral haemangiomas. Brain 1975; 98: $71-80$.

4 Mohan V, Gupta SK, Tuli SM, Sanyl B. Symptomatic vertebral haemangiomas. Clin Radiol 1980; 31: 575-579.

5 Nguyen JP et al. Vertebral haemangiomas presenting with neurologic symptoms. Surg Neurol 1987; 27: $391-397$.

6 Hemmy DC. Vertebral haemangiomas. In Wilkins RH, Rengachary SS (eds). Neurosurgery, McGraw Hill: New Delhi, 1985, pp $1076-1079$

7 Bell RL. Haemangioma of dorsal vertebrae with collapse and compression myelopathy. J Neurosurgery 1955; 12: 570-576.

8 Healy M, Herz DA, Pearl L. Spinal haemangiomas. Neurosurgery. 1983; 13: 689-691.

9 Baker ND et al. Symptomatic vertebral haemangiomas: a report of four cases. Skeletal Radiol 1986; 15: 458-463.

10 Hekster REM, Luyendijk W, Tan TI. Spinal cord compression caused by vertebral haemangiomas relieved by percutaneous catheter embolization. Neuroradiology 1972; 3: 160-164.

11 Esparza J, Castro S, Portillo JM, Roger R. Vertebral haemangiomas: Spinal angiography and preoperative embolization. Surg Neurol 1978; 10: $171-173$.

12 Graham JJ, Yang WC. Vertebral haemangioma with compression fracture and paraperesis treated with preoperative embolization and vertebral resection. Spine 1984; 9: $97-101$.

13 Nikolaus Nicola, Evaldo Lins. Vertebral haemangioma: Retrograde embolisation-stabilisation with methyl methacrylate. Surg Neurol 1987; 27: 481 - 486.

14 Raco A et al. Vertebral haemangiomas with cord compression. The role of embolisation in five cases. Surg Neurol 1990; 34: $164-$ 168.

15 Frankel HL et al. The value of postural reduction in the initial management of closed injuries of the spine with paraplegia and tetraplegia - Part I, Paraplegia 1969; 7: 179-192.

16 Paige ML, Hemmati M. Spinal cord compression by vertebral haemangoma. Paediatr Radiol 1977; 6: $43-45$.

17 Greenspan A et al. Haemangioma of the T6 vertebra with a compression fracture, extradural block and spinal cord compression. Skeletal Radiol 1983; 10: $183-188$.

18 Kosary IA, Braham J, Shacked I, Shaked R. Spinal epidural haematoma due to haemangioma of vertebra. Surg Neurol 1977; 7: $61-62$.

19 Laredo JD, Reizine D, Bard M, Merland JJ. Vertebral haemangiomas: Radiologic evaluation. Radiology 1986; 161: $183-189$.

20 Padovani R et al. Spinal epidural haemangiomas. Spine 1981; 6: $336-340$.

21 Schnyder P, Frankhauser H, Mansouri B. Computed tomography in spinal haemangioma with cord compression. Report of 2 cases. Skeletal Radiol 1986; 15: $372-375$.

22 Ross JS et al. Vertebral haemangiomas: MR Imaging. Radiology 1987; 165, $165-169$

23 Gaston A et al. Haemangiomes vertebraux: Aspects tomodensitometriques et arteriographiques. A propos de 3 cas. Journal of Neuroradiology 1983; 12: 21 - 33 . 
24 MacErlean DP, Shanik DG, Martin EA. Transcatheter embolization of bone tumour arteriovenous malformations. $\mathrm{Br}$ J Radiol 1978; 51: 414-419.

25 Hilal SK, Michelsen JW. Therapeutic percutaneous embolization for extra-axial vascular lesions of the head, neck and spine. $J$ Neurosurg 1975; 43: 275-287.
26 Fox MW, Onofrio M. The natural history and management of symptomatic and asymtomatic vertebral haemangiomas. Journal of Neurosurgery 1993; 78: $36-45$ 